\title{
BTS-BI APPLICATION (INDONESIAN STUDENT TEXT BOOK) BASED ON ANDROID
}

\author{
Endah Riski Kartini \\ Universitas Muhammadiyah Surakarta, Jawa Tengah, Indonesia \\ Email: endahriski21@gmail.com \\ Sri Budi Utami \\ Universitas Muhammadiyah Surakarta, Jawa Tengah, Indonesia \\ Email: sribudi132@gamil.com \\ Opie Octaviana Sari \\ Universitas Muhammadiyah Surakarta, Jawa Tengah, Indonesia \\ Email: opieoctaviana@gmail.com
}

DOI: 10.35445/alishlah.v12i1.174

Accepted: January $5^{\text {th }}$, 2020. Approved: June $28^{\text {th }}, 2020$.

Published: June $30^{\text {th }}, 2020$

\begin{abstract}
This research aims to develop, design, and create innovations in education that can be used in learning, namely Android-based BTS-BI applications that can be used to facilitate teachers and students in implementing the learning process. If teachers and students cannot attend class learning, this application can be utilized. The research method used is a qualitative descriptive approach that was developed using a research and development model. The results of this study are Android-based "BTS-BI" (Indonesian-Student Textbook) application designs. This application contains Indonesian material that has been adapted to the applicable curriculum.
\end{abstract}

Keywords: Learning, Application, BTS-BI, Android 
Al-Ishlah: Jurnal Pendidikan - ISSN: 2087-9490 (p); 2597-940X (e)

Vol. 12, No. 1 (2020)

\title{
APLIKASI BTS-BI (BUKU TEKS SISWA-BAHASA INDONESIA) BERBASIS ANDROID
}

\begin{abstract}
Abstrak
Penelitian ini bertujuan untuk mengembangkan, merancang, dan menciptakan suatu inovasi dalam pendidikan yang dapat digunakan dalam pembelajaran yaitu Aplikasi BTS-BI berbasis Android yang dapat digunakan untuk mempermudah guru dan siswa dalam melaksanakan proses pembelajaran. Apabila guru dan siswa tidak dapat hadir dalam pembelajaran di kelas, maka aplikasi ini dapat dimanfaatkan. Metode penelitian yang digunakan adalah pendekatan deskriptif kualitatif yang dikembangkan dengan menggunakan model penelitian pengembangan (Research and Development). Hasil dari penelitian ini adalah rancangan aplikasi "BTS-BI" (Buku Teks Siswa-Bahasa Indonesia) berbasis Android. Aplikasi ini berisi tentang materi-materi Bahasa Indonesia yang telah disesuaikan dengan kurikulum yang berlaku.
\end{abstract}

Kata Kunci: Pembelajaran, Aplikasi, BTS-BI, Android

\section{PENDAHULUAN}

Dalam Permendikbud No. 71 Tahun 2013 Tentang Buku Teks Pelajaran dan Panduan Guru untuk Pendidikan Dasar dan Menengah, menetapkan bahwa dalam buku teks pelajaran itu sebagai buku siswa yang layak digunakan dalam pembelajaran di sekolah yang harus disusun sesuai dengan kurikulum yang berlaku. Dapat diketahui bahwa pembelajaran yang dilakukan pada proses belajar mengajar merupakan suatu proses yang sangat penting dalam dunia pendidikan. Seperti diketahui bahwa proses pembelajaran memiliki hubungan yang tidak dapat dipisahkan dari pendidikan, karena pembelajaran merupakan suatu kunci keberhasilan dari tujuan pendidikan yang diharapkan dapat merubah perilaku siswa atau pola pikir siswa kearah yang lebih positif. Jihad dan Haris, (2013: 11) menyatakan bahwa pembelajaran merupakan suatu proses bertukar komunikasi antara peserta didik dan pendidik dalam rangka perubahan sikap. Pembelajaran dapat dikatakan baik apabila pembelajaran yang di dalamnya terjadi saling bertukar informasi dalam berlangsungnya proses pembelajaran. Dengan demikian pembelajaran yang telah dilakukan antara guru dan siswa dapat dikatakan sebagai bantuan yang diberikan oleh pendidik yang mempunyai tujuan untuk memberikan ilmu pengetahuan dan keterampilan kepada peserta didik supaya siswa dapat memberikan kontribusi yang baik.

Proses pembelajaran yang telah dilakukan dalam di kelas bukan tidak mungkin tidak memiliki kelemahan. Ada beberapa faktor yang menjadi 
Al-Ishlah: Jurnal Pendidikan - ISSN: 2087-9490 (p); 2597-940X (e)

Vol. 12, No. 1 (2020)

permasalahan dalam kelas diantaranya yaitu: pertama, kurangnya kemampuan personal guru dalam menyampaikan materi pembelajaran. Kedua, pembelajaran yang masih sering digunakan adalah dengan menerapkan metode ceramah dalam menyampaikan materinya pada setiap pertemuan kelas, hal ini memungkinkan siswa dapat merasa bosan sehingga kebanyakan siswa menjadi kurang focus bahkan tidak memperhatikan apa yang telah disampaikan oleh guru selama proses pembelajaran berlangsung. Faktor ini juga dapat menjadi alasan mengapa peserta didik menjadi kurang tertarik pada pembelajaran Bahasa Indonesia, terlebih lagi dengan materi yang disajikan terlalu banyak tulisan-tulisan. Ketiga, belum tercukupinya fasilitas pengajaran sekolah yang mendukung tercapainya pembelajaran, seperti media pembelajaran, buku pedoman, maupun alat praktikum pembelajaran (Ariyani, 2010). Dapat dilihat dari beberapa faktor yang menjadi permasalahan dalam kelas, salah satu faktor diantaranya yang mungkin bisa dibenahi ialah fasilitas pendukung pembelajaran yang berupa buku.

Pada zaman modern seperti sekarang teknologi selalu mengalami perkembangan dari waktu ke waktu serta mengalami kemajuan yang sangat pesat dan cepat. Teknologi yang semakin hari semakin canggih ini dapat menjadi peran utama dalam dunia masyarakat terlebih yang dapat dimanfaatkan untuk kehidupan sehari-hari mereka, sama halnya dengan dunia pendidikan yang semakin hari semakin mengikuti perkembangan teknologi misalnya pada kegiatan pembelajaran siswa di sekolah. Karena pendidikan yang mengikuti perkembangan teknologi di pandang memiliki nilai efektif dan efisiensi serta dapat mempermudah kegiatan pembelajaran dengan menggunakan berbagai media pembelajaran yang berbasis teknologi. Menurut Daryanto (2013:5) media pembelajaran merupakan media yang dapat digunakan sebagai alat dan bahan kegiatan pembelajaran. Ketiadaan media pembelajaran, maka akan berpengaruh pada kegiatan pembelajaran yang memungkinkan dapat mengganggu jalannya proses pembelajaran dan pembelajaran pun tidak akan berjalan dengan baik karena tidak adanya komunikasi antara pendidik dan peserta didik sebab pembelajaran sebagai komunikasi tidak akan berlangsung optimal.

Ketersediaan sistem pendukung pada kegiatan pembelajaran yang dapat diakses secara online oleh siapapun, kapanpun dan dimanapun. Aplikasi pembelajaran atau e-learning berbasis android dapat menambah fasilitas guru dan siswa dalam berkomunikasi, pemberian materi pelajaran dengan tugas dan mata pelajaran secara online dengan mudah dan cepat dapat menghemat waktu karena dapat dilakukan walaupun tidak dapat bertemu secara tatapmuka atau langsung. Dengan adanya aplikasi pembelajaran berbasis android ini diharapkan dapat membantu dan mempermudah proses pembelajaran menjadi lebih optimal. Selain itu aplikasi e-learning ini dapat dijadikan sebagai tempat dan wadah diskusi alternatif untuk membahas dan mengevaluasi materi pembelajaran dengan secara 
Al-Ishlah: Jurnal Pendidikan - ISSN: 2087-949o (p); 2597-940X (e)

Vol. 12, No. 1 (2020)

tidak langsung atau tidak tatap muka, dengan begitu pembelajaran dapat dilaksanakan dimana saja dan kapan saja. Selain untuk wadah dan media diskusi guru dapat juga memanfatkannya untuk melaksanakan atau memberikan tugastugas kepada peserta didik.

Seiring dengan berkembangnya teknologi yang berpengaruh pada dunia pendidikan menuntut para guru lebih inovatif dalam proses pembelajaran. Tidak semua guru mampu mengikuti arus teknologi sebagian guru menganggap bahwa inovatif dalam pembelajaran dianggap sulit dan mahal dalam proses pelaksanaannya dengan begitu banyak guru yang masih menggunakan pola pembelajaran yang lama, yaitu dengan menggunakan metode ceramah. Hal ini perlu diperhatikan agar dunia pendidikan dapat mengikuti perkembangan arus digital dengan guru yang harus mampu menerapkan metode mengajar dengan tepat yang memiliki kreativitas yang tinggi dan mampu berinovatif. Inovatif inilah yang diharapkan dapat meningkatkan kualitas dan kuantitas dalam mutu pendidikan.

Dengan mengikuti pesatnya perkembangan teknologi khususnya dalam bidang pendidikan, terciptanya inovasi dalam media dan metode pembelajaran yang dilakukan guna untuk tercapainya tujuan pembelajaran yang dapat berakibat langsung pada pencapaian hasil belajar siswa. Dari permasalahan yang ada tersebut kami menawarkan sebuah inovasi yang berupa aplikasi yang dapat digunakan serta membantu menunjang kegiatan pembelajaran khususnya Bahasa Indonesia yaitu sebuah aplikasi yang bernama BTS-BI (Buku Teks Siswa-Bahasa Indonesia) aplikasi yang berbasis android yang merupakan bersifat e-learning. Seperti halnya BSE (Buku Sekolah Elektronik) yang merupakan salah satu buku ajar pembelajaran yang kini banyak diterapkan dalam berbagai sekolah di Indonesia. BSE memiliki beberapa kelebihan yang membuatnya lebih diminati oleh guru. Selain itu, jika dibandingkan dengan buku ajar pembelajaran konvensional. BSE mudah dijangkau dengan cara dapat mengunduhnya dalam situs resmi Depdikbud, keserasian hubungan isi dengan kurikulum, bahasa yang digunakan juga mudah dipahami oleh siapapun, serta sudah lulus uji dari penelitian BHSP sebagai buku ajar teks yang layak dan mampu digunakan dalam kegiatan belajar mengajar.

Aplikasi BTS-BI merupakan aplikasi yang berbasis android yang dibuat khusus hanya untuk mata pelajaran Bahasa Indonesia dengan fitur yang disajikan pada aplikasi ini mencakup semua materi Bahasa Indonesia di tingkat jenjang pendidikan SMP dan SMA. Pada aplikasi ini tidak hanya berisi materi-materi ajar saja tetapi dalam aplikasi ini juga terdapat soal-soal latihan yang sesuai dengan materi dan dapat dimanfaatkan guru untuk mengambil nilai ulangan harian. Tujuan dibuatnya aplikasi ini selain untuk pembelajaran juga diharapkan siswa 
Al-Ishlah: Jurnal Pendidikan - ISSN: 2087-949o (p); 2597-940X (e)

Vol. 12, No. 1 (2020)

mampu mengoptimlisasikan penggunaan teknologi dengan menggunakanya sebaik mungkin.

Aplikasi ini dirancang untuk diterapkan pada sistem yang bernama android. Untuk istilahnya sendiri menurut Nazruddin Safaat H (2011:1), mengartikan android merupakan sebuah rancangan sistem yang dioperasikan untuk sebuah perangkat mobile berbasis linux yang meliputi sistem operasi, middleware dan aplikasi. Sebuah android yang menyediakan platform yang terbuka untuk para pengembang atau pengguna untuk menciptakan aplikasi mereka sendiri. Android memiliki sistem yang bersifat open source yang hal ini mampu diuraikan secara bebas oleh siapapun dan boleh disebarkan paada situs resmi android dalam play store google. Android dapat secara mudah diintergrasikan dengan cepat pada produk Google seperti Google Docs, Gmail, Google Reader, Bloger dan masih banyak lagi. Dengan aplikasi ini, peneliti sangat yakin akan memberikan stimulus yang baik bagi siswa dalam meningkatkan motivasi belajar. Aplikasi ini juga dapat dijadikan media bagi guru untuk meningkatkan efisiensi dalam proses pembelajaran.

\section{METODE PENELITIAN}

Penelitian ini menggunakan teknik pendekatan deskriptif kualitatif yang menggambarkan aplikasi BTS-BI. Data yang telah didapatkan, lalu dianalisis menggunakan statistik deskriptif kualitatif. Analisis deskriptif kualitatif ini digunakan untuk memberi gambaran karakteristik data yang telah didapatkan di setiap variabel. Cara yang digunakan ini bertujuan agar memberi kemudahan dalam memahami data yang ada pada setiap prosesnya.

Pada penelitian ini menggunakan penelitian pengembangan. Penelitian pengembangan (research and development) dikarenakan dalam penelitian ini berbasis pengembangan. Metode yang dilakukan dengan melalui 3 tahap yaitu 1) analisis kebutuhan yang berupa pengumpulan informasi yang diperlukan, 2) desain pembelajaran meliputi pemilihan dan pengembangan materi serta struktur rancangan produk, 3) produksi meliputi penggabungan elemen-elemen yang telah tersedia menjadi satu kesatuan yang telah dirancang. 
Al-Ishlah: Jurnal Pendidikan - ISSN: 2087-949o (p); 2597-94oX (e)

Vol. 12, No. 1 (2020)

\section{HASIL DAN PEMBAHASAN}

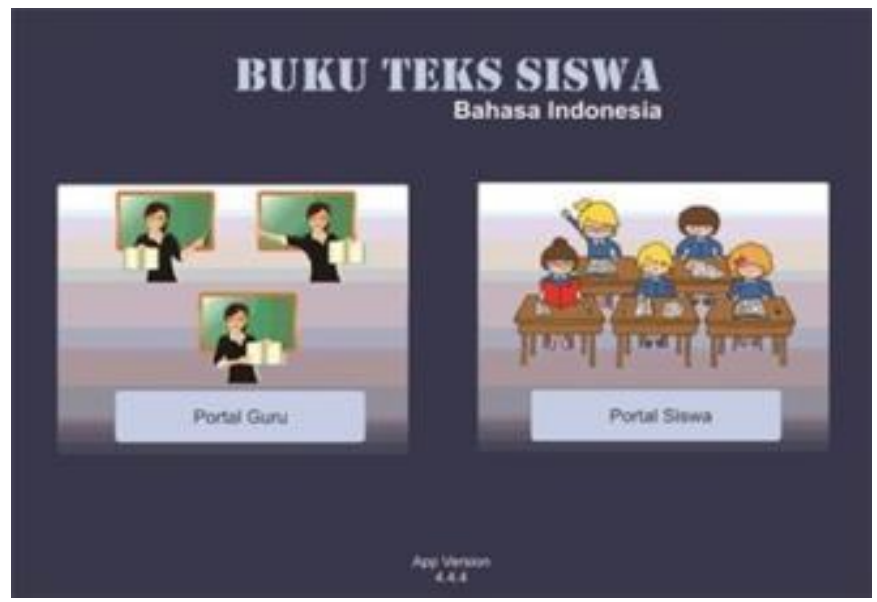

Gambar 1 Tampilan Bagian Depan
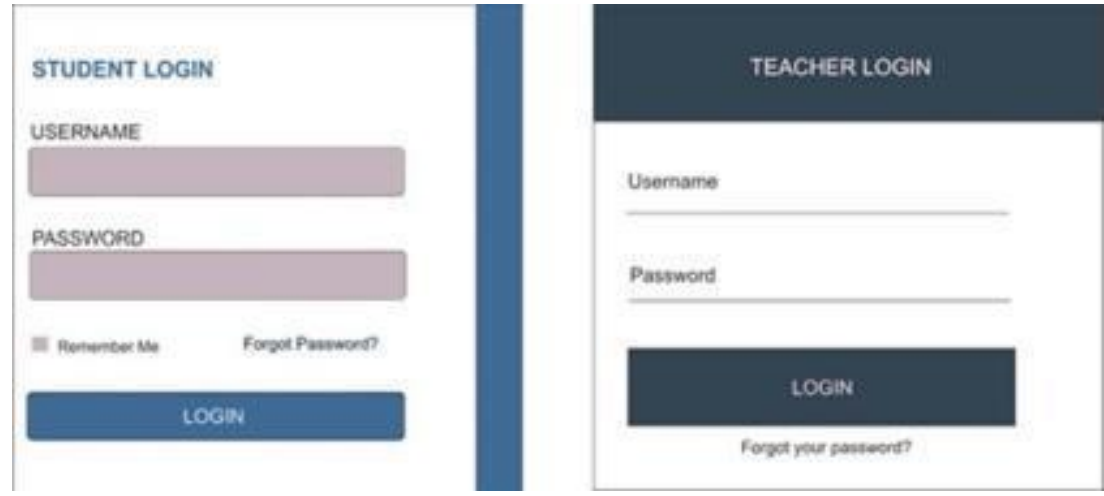

Gambar 2 Tampilan Bagian Login (Masuk)

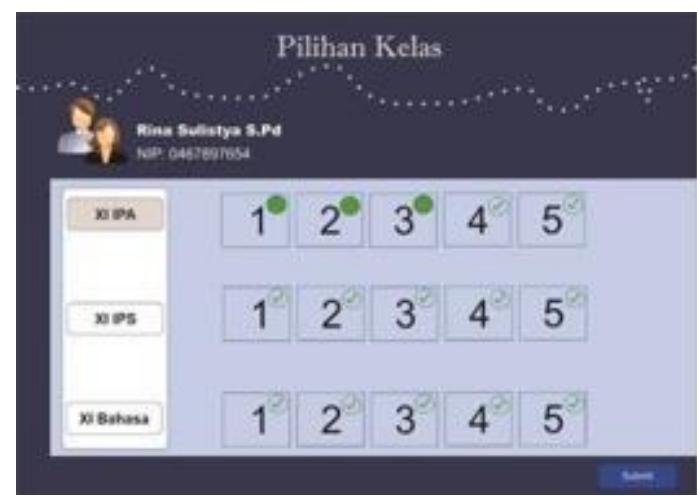

Gambar 3 Tampilan Pilihan Kelas untuk Guru 
Al-Ishlah: Jurnal Pendidikan - ISSN: 2087-949o (p); 2597-94oX (e)

Vol. 12, No. 1 (2020)
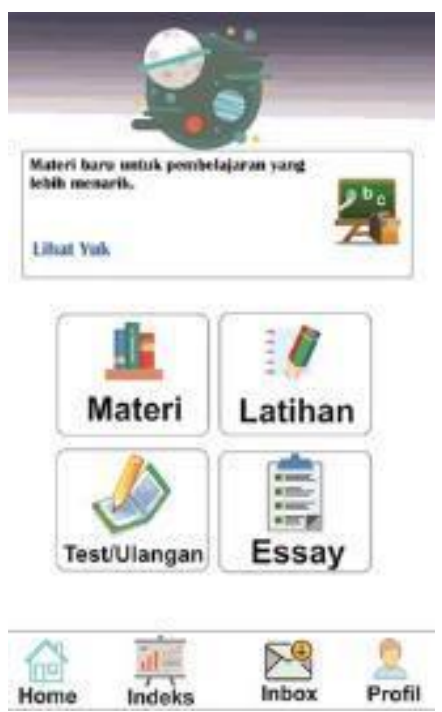

Gambar 4 Tampilan Home
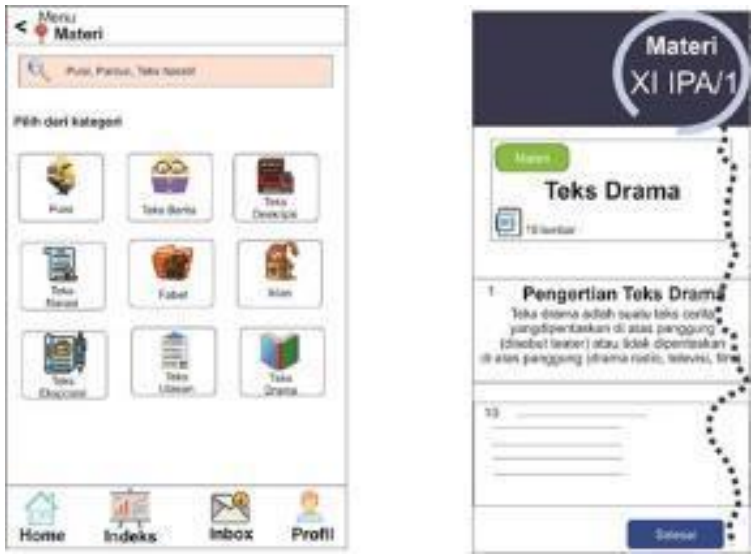

Gambar 5 Tampilan dari Fitur Materi
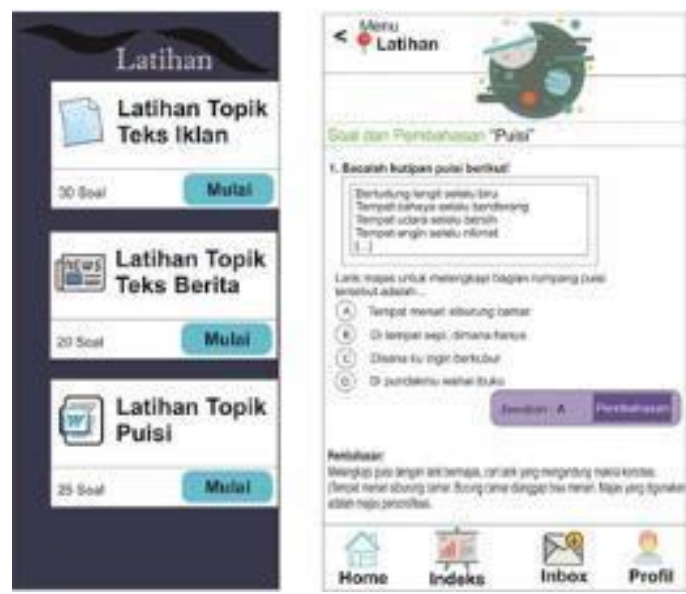

Gambar 6 Tampilan Fitur Latihan 
Al-Ishlah: Jurnal Pendidikan - ISSN: 2087-949o (p); 2597-94oX (e)

Vol. 12, No. 1 (2020)

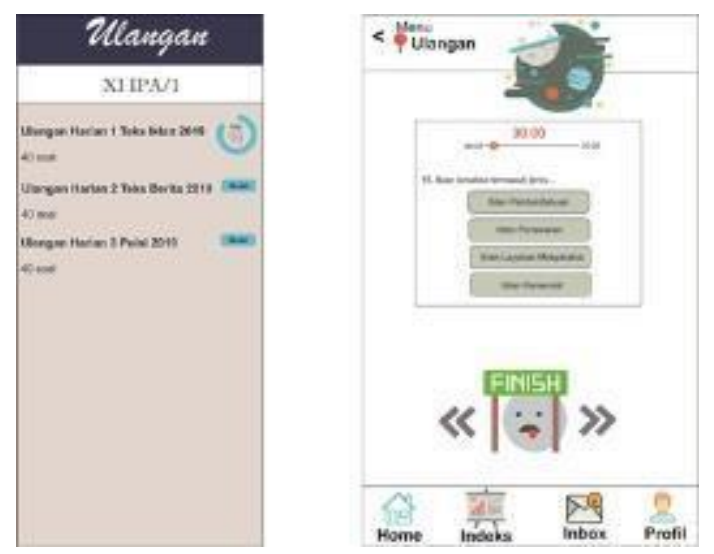

Gambar 7 Tampilan Fitur Test/Ulangan
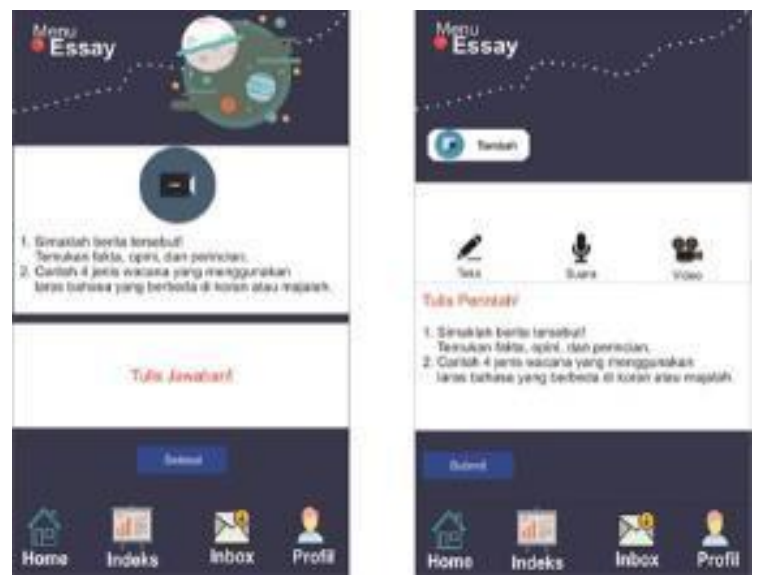

Gambar 8 Tampilan Fitur Essay

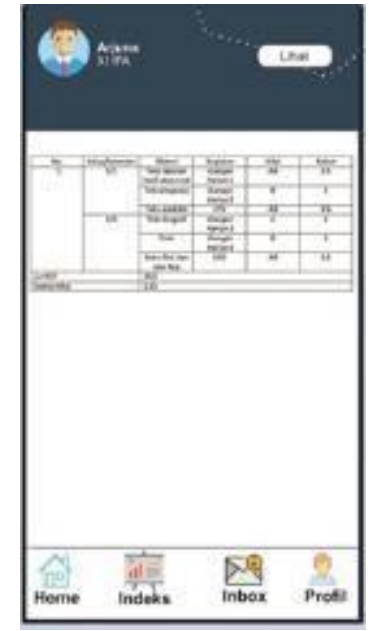

Gambar 9 Tampilan Fitur Indeks Siswa 
Al-Ishlah: Jurnal Pendidikan - ISSN: $2087-9490$ (p); 2597-94oX (e)

Vol. 12, No. 1 (2020)

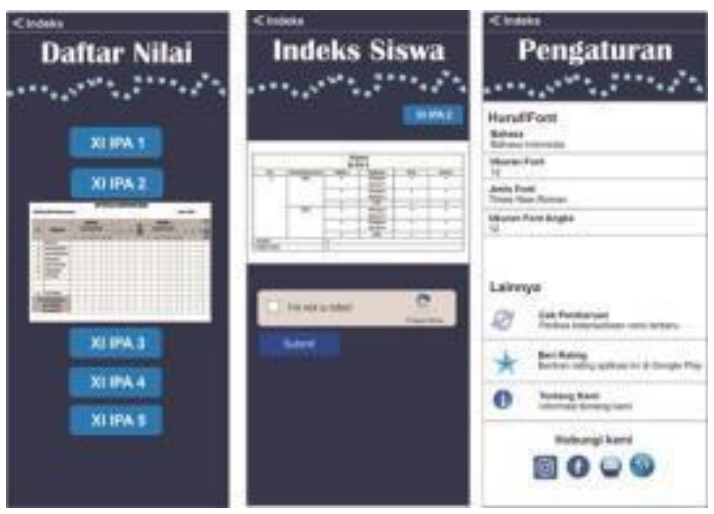

Gambar 10 Tampilan Fitur Indeks Guru

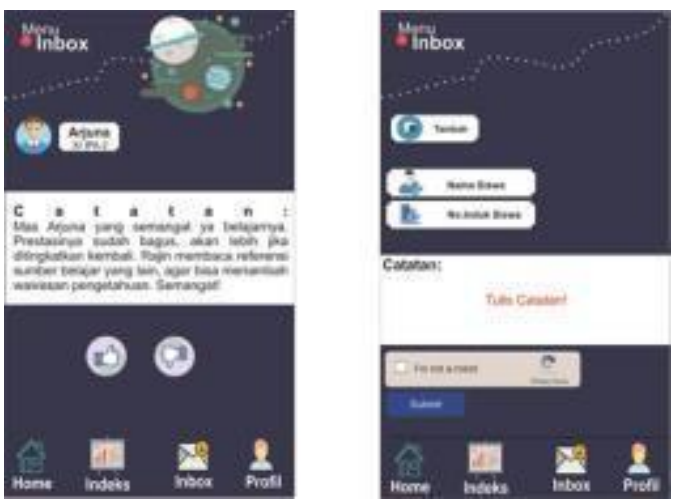

Gambar 11 Tampilan Fitur Inbox Siswa dan Guru
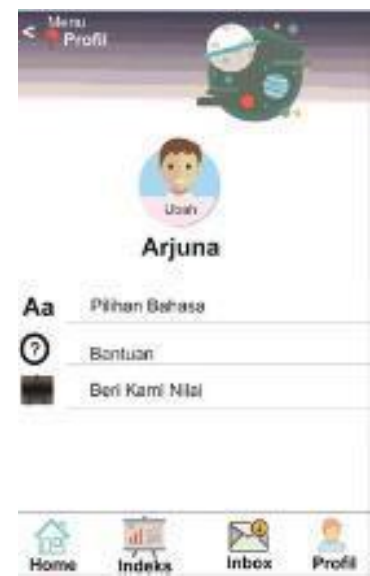

Gambar 12 Tampilan Fitur Profil 
Al-Ishlah: Jurnal Pendidikan - ISSN: $2087-9490$ (p); 2597-940X (e)

Vol. 12, No. 1 (2020)

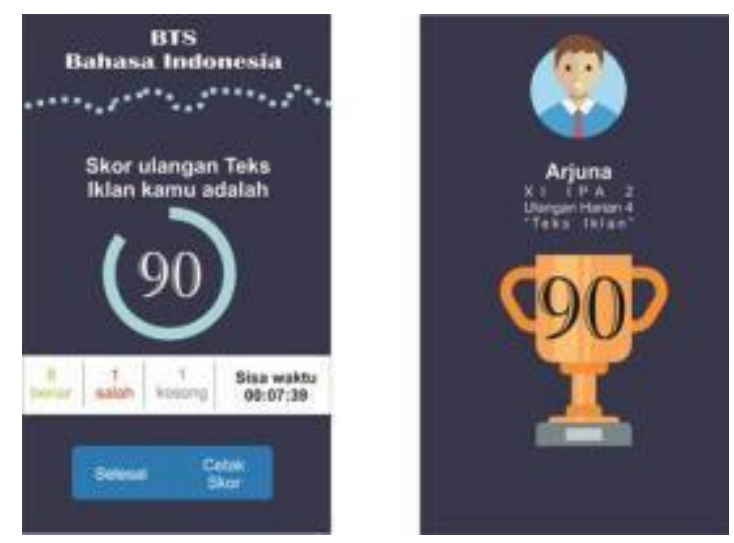

Gambar 13 Tampilan Fitur Cetak Skor

BTS-BI (Buku Teks Siswa-Bahasa Indonesia) merupakan sebuah aplikasi berbasis android yang memuat materi-materi pembelajaran khususnya Bahasa Indonesia. BTS-BI ini adalah sebuah aplikasi yang dibuat untuk menggantikan buku teks cetak. Di dalam aplikasi ini dapat ditemukan berbagai materi-materi Bahasa Indonesia, latihan-latihan soal, dan juga soal-soal yang dapat digunakan sebagai ulangan harian. BTS-BI juga memuat berbagai gambar, video, atau apapun yang berhubungan dengan materi ajar yang dapat menarik siswa untuk belajar dan dapat merangsang kreativitas dan pengetahuan siswa. Di dalam aplikasi ini guru dapat melihat bagaimana perkembangan siswa dalam belajar Bahasa Indonesia dengan adanya fitur indeks yang menunjukkan nilai siswa dalam setiap materi yang diajarkan. BTS-BI ini ditujukan untuk jenjang SMP dan SMA. BTS-BI dibuat untuk mempermudah guru dalam mengajar khususnya pada mata pelajaran Bahasa Indonesia. Apabila guru sedang berhalangan hadir dalam pembelajaran tatap muka di kelas, maka aplikasi ini dapat dijadikan alternatif guru untuk menyampaikan materi-materi pembelajaran agar materi-materi Bahasa Indonesia yang belum disampaikan dalam pembelajaran di kelas dapat disampaikan dan diajarkan dengan tepat waktu dan maksimal. Isi dalam BTS-BI ini akan disesuaikan dengan kurikulum yang sedang berlaku. Penggunaan aplikasi ini diharapkan menjadi media pembelajaran yang memiliki arah pembelajaran yang lebih efektif dan efisien.

Dalam kegiatan pembelajaran biasanya dilakukan dengan tatap muka di kelas. Tetapi, bagaimana jika guru tiba-tiba tidak dapat hadir ke kelas karena ada beberapa hal penting yang tidak bisa ditinggalkan atau bagaimana jika siswa pada saat pembelajaran tidak hadir dalam kelas karena berbagai alasan. Jika guru tidak dapat hadir ke kelas untuk mengajar, guru dapat langsung menginstruksi siswa dan memantaunya untuk membuka aplikasi ini untuk memahami atau mengerjakan soal-soal yang berkaitan dengan materi dengan jarak jauh sekalipun. Siswa yang tidak dapat hadir melakukan kegiatan tatap muka di kelas dan dalam 
Al-Ishlah: Jurnal Pendidikan - ISSN: 2087-949o (p); 2597-940X (e)

Vol. 12, No. 1 (2020)

waktu yang bersamaan dilakukan ulangan harian maka siswa dapat membuka aplikasi ini untuk mengerjakan ulangan hariannya dari rumah atau di manapun siswa berada agar ia tidak perlu melakukan ulangan susulan. Maka, BTS-BI ini dibuat untuk memaksimalkan tugas guru dan mengoptimalkan kegiatan pembelajaran. BTS-BI membantu guru untuk menyesuaikan materi pembelajaran agar selesai sesuai dengan jam pembelajaran yang telah ditentukan. Seperti menggunakan buku teks cetak pada umumnya BTS-BI ini berisi materi lengkap Bahasa Indonesia sesuai dengan kompetensi inti dan kompetensi dasar dalam kurikulum yang berlaku. Tetapi bedanya, BTS-BI ini dilengkapi dengan adanya fitur-fitur yang melengkapi tugas guru lainnya. Misalnya, memasukkan dan memantau nilai-nilai siswa dan juga catatan-catatan yang diperlukan siswa untuk meningkatkan kreativitas dan perkembangan siswa dalam kegiatan pembelajaran.

Kelebihan dari aplikasi BTS-BI ini yang pertama adalah kegiatan pembelajaran dapat berjalan dengan efektif dan efesien. Memaksimalkan guru dalam menyampaikan materi pembelajaran dan juga merangsang kreativitas serta pemahaman siswa terhadap materi pembelajaran Bahasa Indonesia. Kedua, mengurangi jumlah kertas yang digunakan (paperless) dalam kegitan pembelajaran. Selanjutnya adalah membantu guru dalam memasukkan nilai siswa karena dengan aplikasi ini skor yang didapatkan oleh siswa dapat langsung masuk ke dalam akun yang dimiliki guru.

Kekurangan aplikasi BTS-BI adalah jaringan internet. Jaringan internet yang belum merata di setiap daerah akan sedikit menghambat penggunaan aplikasi ini. Dikarenakan aplikasi ini perlu adanya jaringan internet untuk membantu membuka gambar dan video yang ada di dalam aplikasi. Selanjutnya yang menjadi kekurangan aplikasi ini adalah kurangnya interaksi dan komunikasi antara siswa dan guru secara langsung yang mungkin saja menyebabkan kesalahan pemahaman saat menyampaikan tugas. Karena aplikasi BTS-BI ini berbasis android, maka siswa dan guru harus menguasai penggunaan telepon seluler yang berbasis android. Apabila guru dan siswa kurang menguasi penggunaan android maka dapat dimungkinkan dalam menjalankan aplikasi ini terjadi kesalahan. Karena aplikasi ini dilengkapi dengan banyak fitur.

\section{A. Bagian Depan}

Fitur ini menampilkan awal aplikasi BTS-BI yang membedakan cara LogIn bagian dari guru dan peserta didik. Hal ini dilakukan dengan alasan fitur didalamnya sedikit berbeda antara keduanya. Tampilan ini yakni terdapat Portal Guru dan Portal Siswa. Maka dari itu tampilan fitur ini dibuat menarik, agar meningkatkan minat siswa dalam pembelajaran khususnya Bahasa Indonesia. 
Al-Ishlah: Jurnal Pendidikan - ISSN: 2087-9490 (p); 2597-940X (e)

Vol. 12, No. 1 (2020)

a. Portal Guru

Bagian ini merupakan awal dari membuka aplikasi BTS-BI untuk Guru. Fitur ini selanjutnya akan mengantarkan guru menuju bagian fitur Log-In dan bagian dari aplikasi lainnya.

b. Portal Siswa

Bagian ini merupakan awal dari membuka aplikasi BTS-BI untuk peserta didik. Fitur ini akan mengantar peserta didik menuju fitur bagian Log-In sampai fitur akhir lainnya.

\section{B. Fitur Log-In}

Fitur ini merupakan bagian dari Log-In pengguna aplikasi BTS-BI. Fitur ini juga terdapat perbedaan dari peserta didik dan guru. Perbedaan yang paling terlihat adalah bagian tampilan. Pada fitur ini terdapat dua komponen yaitu Student Login (Masuk Siswa/Peserta Didik) dan Teacher Login (Masuk Guru). Bagian ini tidak memerlukan Sign Up maupun Create New Account karena bagian peserta didik menggunakan Password (kata sandi) dari bagian guru. Begitu pula dengan guru karena guru perlu menggunakan dengan sederhana. Pada Student Login (Masuk Siswa/Peserta Didik) penjelasan bagian-bagiannya sebagai berikut:

a. Username (Nama Pengguna) : Bagian ini peserta didik hanya perlu mengetikkan nama lengkapnya. Abjad dari penulisan nama perlu diperhatikan. Contoh benar "Sri Budi Utami", contoh salah "sri budi utami".

b. Password (Kata Sandi) : Bagian ini peserta akan mengisi kata sandi yang diberikan oleh guru pengampu. Dalam hal ini akan satu kelas akan memiliki kata sandi yang sama, yang membedakan hanya bagian nama pengguna siswa saja. Contoh "KJ0573”.

c. Remember me (Ingat aku) : Bagian ini diberikan untuk memberikan solusi ketika tiba-tiba macet maupun jaringan internet tidak stabil. Maka dari fitur ini akan membantuk peserta didik menuju menu yang tadi ia kerjakan maupun ia pelajari.

d. Forgot Password (Lupa Kata Sandi) : Bagian diberikan untuk membantu peserta didik apabila ia salah menuliskan kata sandi yang diberikan oleh guru.

Pada Teacher Login (Masuk Guru/Pengampu) penjelasan bagian-bagiannya sebagai berikut:

a. Username (Nama Pengguna) : Bagian ini guru akan menuliskan nama lengkap dan gelarnya. Abjad dalam penulisan nama pengguna juga harus diperhatikan. Hal itu untuk menghindari tidak terdekteksi sistem operasinya. 
Al-Ishlah: Jurnal Pendidikan - ISSN: 2087-9490 (p); 2597-940X (e)

Vol. 12, No. 1 (2020)

Contoh benar "Annisa Samawasti S.Pd.", contoh salah "annisa samaswati p.pd.".

b. Password (Kata Sandi) : Bagian ini guru akan menuliskan kata sandi dengan menggunakan NIP (Nomor Induk Pegawai). Penggunaan NIP sebagai kata sandi dikarenakan bawaan sistem yang disesuaikan dengan bagian pendidikan, maka dari itu untuk memudahkan dibuat dengan menggunakan NIP masing-masing saja. Contoh "198503302003121002".

c. Forgot Password (Lupa Kata Sandi) : Bagian ini ditambahkan untuk membantu guru jika guru menuliskan angka NIP kurang maupun salah angka.

\section{Pilihan Kelas (Fitur untuk Guru)}

Perbedaan anatara bagian peserta didik dan guru sudah dapat terlihat yakni fitur pilihan kelas yang hanya dikhususkan pada guru/pengampu yang akan diampu olehnya. Pilihan kelas disinilah yang terdapat kata sandi untuk para peserta didik masuk pada aplikasi BTS-BI. Suatu sekolah pasti memiliki guru/pengampu khusunya Bahasa Indonesia tidak hanya satu guru/pengampu saja. Umumnya satu guru akan memegang 3-4 kelas dalam jenjang kelas. Pada tampilannya akan terdapat nama lengkap serta NIP guru/pengampu yang sesuai dengan Login awal tadi. Penjelasan bagian-bagiannya sebagai berikut:

1. Jenjang Kelas: Pada bagian ini guru akan memilih kelas yang menjadi bagiannya untuk melangsungkan pembelajaran dalam kelas. Contoh dari jenjang kelas ini yakni:
a. $\mathrm{X}$
(X IPA 1, X IPA 2, X IPA 3, X IPA 4, X IPA 5)
(X IPA 1, X IPA 2, X IPA 3, X IPA 4, X IPA 5)
(X BAHASA 1, X BAHASA 2, X BAHASA 3)
b. XI
(XI IPA 1, XI IPA 2, XI IPA 3, XI IPA 4, XI IPA 5)
(XI IPA 1, XI IPA 2, XI IPA 3, XI IPA 4, XI IPA 5)
(XI BAHASA 1, XI BAHASA 2, XI BAHASA 3)
c. XII (XII IPA 1, XII IPA 2, XII IPA 3, XII IPA 4, XII IPA 5)
(XII IPA 1, XII IPA 2, XII IPA 3, XII IPA 4, XII IPA 5)
(XII BAHASA 1, XII BAHASA 2, XII BAHASA 3)

2. Langkah-langkah guru/pengampu dalam memilih kelas sebagai berikut:

a. Klik pada bagian jenjang kelas, maka akan muncul kolom-kolom angka kelas yang dapat dipilih.

b. Klik centang diatas angka yang tertera sampai muncul warna hijau.

c. Jika sudah selesai klik submit yang tertera bagian bawah.

d. Ketika submit sukses maka akan dengan otomatis terunduh daftar nama siswa berserta kata sandi yang tertera. 
Al-Ishlah: Jurnal Pendidikan - ISSN: 2087-9490 (p); 2597-940X (e)

Vol. 12, No. 1 (2020)

\section{Home (Beranda)}

Bagian ini fitur bagian guru dan peserta didik sama. Tampilan fitur ini terdapat kolom-kolom yakni (Materi, Latihan, Test/Ulangan, dan Essay).

a. Materi

Bagian ini akan menampilkan materi yang akan dipelajari dalam kegiatan KBM (Kegiatan Belajar Mengajar) saat itu. Fitur ini juga memanfaatkan kolom-kolom disertai dengan sentuhan gambar kartun yang akan menarik minat peserta didik. Materi yang disajikan disesuaikan dengan KI/KD Permendikbud No. 37 Tahun 2018.

b. Latihan

Fitur ini akan menampilkan beberapa soal latihan bagi peserta didik dalam mempelajari topik materi yang sedang dibahas. Bagian ini pula siswa harus mengerjakan beberapa soal yang disajikan, namun tidak ada skor/hasil. Maka dari itu ditambahkan pula pembahasan agar siswa lebih mudah memahami soal yang tengah dikerjakan. Pembahasan tersebut akan muncul ketika siswa telah meng-klik salah satu jawaban dari soal tersebut. Bagian ini sepenuhnya dijalankan oleh sistem yang beroperasi. Maka dari itu guru hanya bisa mengawasi tidak dapat mengubah, mengganti, mauoun menambahkan soal.

c. Test/Ulangan

Fitur ini akan menampilkan soal yang hasil akhirnya terdapat perolehan skor siswa. Fitur ini juga disupport dengan audio bahkan video. Pengerjaan soal ini akan dibatasi waktu yang telah ditentukan. Soal ini berbentuk sejenis pilihan ganda. Siswa dapat memilih jawaban yang menurutnya benar. Pembuatan soal guru tidak turun langsung, sistem yang telah menyiapkan. Selesai mengerjakan siswa dapat melihat perolehan skornya.

d. Essay

Fitur ini merupakan bagian untuk mengerjakan atau menguji kompetensi siswa yang berkenaan dengan pendapat atau jawaban yang hendak tertulis. Contoh "Komptensi yang hendak dicapai: Menyimak", maka dari itu dibuat fitur ini untuk mengembangkan pencapaian kompetensi siswa.

\section{E. Fitur Indeks (Perkembangan Studi)}

Fitur ini akan menampilkan capaian perkembangan studi siswa selama belajar dalam sekolah tersebut. Kata lain dari fitur ini adalah raport mata pelajaran tertentu. Siswa akan dapat melihat pembaharuan perkembangan studi setiap satu semester sekali, yakni setelah melaksanakan UAS (Ujian Akhir Semester).

a. Indeks Siswa bagian-bagiannya meliputi (No, Kelas/Semester, Materi, Kegiatan, Nilai, Bobot, Jumlah, Indeks Nilai). 
Al-Ishlah: Jurnal Pendidikan - ISSN: 2087-9490 (p); 2597-940X (e)

Vol. 12, No. 1 (2020)

b. Indeks Guru bagian-bagiannya meliputi (Daftar Nilai, Indeks Siswa, Pengaturan). Hal ini guru/pengampu melakukan input data secara manual namun sebelumnya telah diolah dengan bantuan sistem, jadi guru hanya mengecek apakah sudah benar data yang tersajikan. Setelah dirasa benar guru akan melakukan submit dan data tersebut akan langsung masuk pada bagian siswa yang akan dituju.

\section{F. Fitur Inbox (Pesan)}

Fitur ini akan memberi pesan/catatan akan prestasi dari siswa tersebut. Catatan diberikan dengan tujuan untuk memotivasi serta memberi nasehat kepada peserta didik. Pesan untuk siswa ini dapat diberikan setelah test/ulangan maupun akhir semester. Tampilan pada fitur antara guru dan peserta didik dipastikan berbeda.

a. Inbox Siswa bagian-bagiannya meliputi (Nama, Kelas, Catatan yang diberi dari guru/pengampu, dan tombol untuk suka/tidak suka bagian bawah).

b. Inbox Guru bagian-bagiannya meliputi (Nama Siswa, Nomor Induk Siswa, Tempat untuk menulis catatan siswa). Jika dirasa sudah selesai klik bagian I'm not a robot kemudian submit. Hal itu akan tersampaikan kapada siswa yang ingin dituju.

\section{G. Fitur Profil}

Fitur ini akan menampilkan yang akan membantu pengguna aplikasi BTSBI untuk mengatur tampilan foto profil maupun hal-hal yang berkaitan dengan aplikasi ini.

\section{H. Fitur Cetak Skor}

Fitur ini dilakukan apabila siswa menginginkan skor/nilai UH (Ulangan Harian) suatu topik akan dicetak untuknya. Hal ini dilakukan dengan bantuan guru dalam prosesnya. Bagian-bagian cetak skor/nilai terdapat sebagai berikut:
a. Nama Siswa
c. Kegiatan \& Topik
b. Jenjang Kelas
d. Skor/Nilai

\section{SIMPULAN}

Aplikasi BTS-BI (Buku Teks Siswa-Bahasa Indonesia) ini dirancang untuk memudahkan guru dan siswa yang saat pembelajaran berhalangan hadir di kelas. Jadi, aplikasi ini dapat dimanfaatkan untuk memaksimalkan materi Bahasa Indonesia yang belum disampaikan atau diajarkan saat guru di kelas. Aplikasi ini diharapkan bisa optimal digunakan dalam pembelajaran karena aplikasi ini adalah 
Al-Ishlah: Jurnal Pendidikan - ISSN: 2087-9490 (p); 2597-940X (e)

Vol. 12, No. 1 (2020)

sebagai media pembelajaran. Pengembangan media pembelajaran ini dikembangkan menggunakan metode prosedural. Fitur yanga ada dalam aplikasi ini mencakup mengenai semua materi Bahasa Indonesia SMP dan SMA yang telah disesuaikan dengan kurikulum yang berlaku. Selain dapat mempelajari materi ajar, dalam aplikasi ini juga dapat dimanfaatkan untuk pengambilan nilai ulangan harian siswa. Karena dalam aplikasi ini dilengkapi dengan soal-soal latihan sesuai dengan materi.

\section{DAFTAR PUSTAKA}

Anna, Ya Ni. (2011). "Comparing the Effectiviness of Classroom and Online Learning: Teaching Research Methods". Journal Of Public Education. 19(2): 199-215.

Buulolo, E. Fori. (2016). “Aplikasi Pembelajaran Bahasa Nias Menggunakan Computer Asisted Intruction”. Jurnal Infotek STIEKOM. 1(1): 33-35.

Darmika, I Putu., et al. (2017). "Penggunaan E-Learning Dalam Pembelajaran Bahasa Indonesia di SMA Negeri Bali Mandara". e-Journal Jurusan Pendidikan Bahasa dan Sastra Indonesia. 7(2): 1-12.

Dewi, Fenita. (2015). "Proyek Buku Digital: Upaya Peningkatan Keterampilan Abad 21 Calon Guru Sekolah Dasar Melalui Model Pembelajaran Berbasis Proyek". Metodik Didaktik. 9(2): 1-15.

Dongsong Zhang, at al. (2004). "Can E-Learning Replace Classroom Learning?". Communication of ACM. 47(5): 75-79.

Dongsong Zhang, at al. (2006). "Instructional video in e-learning: Assessing the impact of interactive video on leraning effectiveness". Information and Management. 43: 15-27.

Douglas, J. Hacker, Dale S. Niederhauser. (2000). "Promoting Deep and Durable Learning in the online classroom". New Direction for Teaching and Learnning. 83.

Fatimah, Asri Siti, Santiana. (2017). "Teaching In $21^{\text {st }}$ Century: StudentsTeachers' Perceptions Of Technology Use In The Classroom". Script Journal: Journal of Linguistic and English Teaching. 2(2): 125-135.

Gardner, Howard, and Thomas Hatch. (1999). "Multiple Intelligence Go to School Educational Implications of the Theory of Multiple Intelligences". Educational Researcher. 18(8): 4-10. 
Al-Ishlah: Jurnal Pendidikan - ISSN: 2087-9490 (p); 2597-940X (e)

Vol. 12, No. 1 (2020)

Hidayati, Nur and Aciek Ida Wuryandari. (2012). "Media Design for Learning Indonesian in Junior High School Level”. Procedia Social and Behavioral Science. 67: 490-499.

Huda, Miftakhul. (2018). "Pembelajaran Inovatif Bahasa Indonesia: Implementasi Strategi Pengembangan Paragraf dan Tanya Jawab Antarsiswa”. Warta. 18(2): 145-152. DOI: https://doi.org/10.23917/warta.v18i2.1955

Indhaka, Willy Alif; Eko Supraptono; Nanik Sugiarti. (2016). “ Penerapan Buku Sekolah Elektronik Berbasis Android dalam Materi Ajar Besaran dan Satuan". Jurnal Penelitian Tindakan Kelas, 17 (2) : 1-8.

Kuswanto, Joko., dan Ferri Radiansah. (2018). "Media Pembelajaran Berbasis Android Pada Mata Pelajaran Sistem Operasi Jaringan Kelas XI". Jurnal Media Infotama. 14(1): 15-20.

Liaw Shu-Sheng. (2008). 'Investigating Students' Perceived Satisfaction, Behavioral Intention, and Effectiveness of E-Learning: A Case Study of The Blackboard System". Computers \& Education. 51: 864-873.

Lin Kan-Min. (2011). "E-Learning Continuance Intention: Moderating Effects of User E-Learning Experience”. Computers \& Education. 56: 525-526.

Muyaroah, Siti., dan Mega Fajarita. (2017). "Pengembangan Media Pembelajaran Berbasis Android dengan Menggunakan Adobe Flash CS 6 pada Mata Pelajaran Biologi". Innovative Journal of Curriculum and Educational Technology. 6(2): 79-83.

Nyura, Yusni. (2010). "Pembuatan Aplikasi Pembelajaran Bahasa Inggris pada Handphone dengan J2ME”. Jurnal Informatika Mulawarman. 5(3): 18-27.

Paechter, Manuela, at al. (2010). "Students' expectations of, and experiences in elearning: Their relation to learning achievements and course satisfaction". Computers \& Education. 54: 222-229.

Qamarruzzaman, M. Haris; Ferdiyani Haris. (2016). “ Aplikasi Mobile Perpustakaan Berbasis Android (Studi Kasus Perpustakaan STMIK Palangkaraya)". Jurnal Saintekom, 6 (1) : 59-70.

Shah, Samira and Murtaza Ali. (2012). "An Investigation into the Applivation of Educational Technology at Higher Educational Institutions". Theory And Practice In Language Studies. 2(7): 1420-1429. 
Al-Ishlah: Jurnal Pendidikan - ISSN: 2087-9490 (p); 2597-940X (e)

Vol. 12, No. 1 (2020)

Skourlas Christos. (2016). "Intergration of Institutional Repositories and eLearning platforms for supporting disabled students in the Higher Education Context". Library Review. 65: 1-33.

Susanto, Heri., et al. (2016). "Aplikasi Pembelajaran Berbasis Android (ELearning) Di MA.Daruttaqwa Gresik". Information Technology Journal. 2(2): 82-88.

Veri, John., dan Eko Prasetia. (2017). "Perancangan Dan Pembuatan Aplikasi Media Pembelajaran Perakitan Komputer Berbasis Android”. Jurnal Pendidikan dan Teknologi Informasi. 4(2): 219-229.

Wang Tzu-Hua. (2011). "Developing Web-based assessment strategies for facilitating junior high school students to perform self-regulated learning in an e-Learning environment". Computers \& Education. 57: 1801-1812.

Wati, Tuji Rochma; Heri Sismoro. (2014). “Analisis dan Perancangan aplikasi Android Buku Dunia Tumbuhan (Plantae)”. Jurnal DASI, 15 (1) : 61-67. 